МУРАДЯН Л. А., канд. техн. наук, доцент кафедри «Вагони та вагонне господарство», ШАПОШНИК В. Ю., молодший науковий співробітник галузевої науково-дослідної лабораторії «Вагони», керівник 3 якості випробувальної лабораторії вагонів (Дніпропетровський національний університет залізничного транспорту імені академіка В. Лазаряна)

\title{
Автоматична ідентифікація окремих частин транспортного засобу при впровадженні нових концепцій системи технічного обслуговування та ремонту
}

Метою роботи є вдосконалення методу автоматичної ідентифікації вагона та його окремих складових в рамках впровадження нових концепцій системи технічного обслуговування та ремонту

Подальший розвиток систем автоматичної ідентифікації вантажних вагонів повинен передбачати можливість автоматичної ідентифікації окремих вузлів та деталей вагонів. На думку авторів найбільш повно вимогам, які пред'являються до таких систем, відповідають RFID системи для несамохідного рухомого складу. Ключові слова: рухомий склад, система автоматичної ідентифікації, RFID системи, система технічного обслуговування та ремонту.

\begin{abstract}
Вступ
Впровадження на залізницях систем автоматичної ідентифікації рухомого складу (далі - CAI) дозволяє оперативно отримувати інформацію про параметри (номер, тип, осність та ін.) вагонів, локомотивів та іншого рухомого складу в реальному режимі часу. Завдяки цьому стає можливим впровадження нових концепцій системи технічного обслуговування та ремонту (надалі - СТОіР).

Для вирішення проблеми автоматичної ідентифікації залізничних транспортних засобів залізниць у 1960-1970 роках на залізницях різних країн почали впроваджуватися оптичні системи ідентифікації. Однак через важкі умови експлуатації рухомого складу ці розробки не набули широкого застосування [1].
\end{abstract}

\begin{tabular}{l}
\hline Аналіз досліджень і публікацій \\
\hline \multicolumn{4}{c}{ Актуальним завданням залишається підвищення } \\
точності та надійності САI, іх параметрів та \\
характеристик. Відома технологія ручного обліку \\
вагонів які прибули на станцію, вже давно \\
неефективна. Тепер розроблені різні системи \\
ідентифікації рухомих одиниць, деякі використовують \\
встановлені на залізничному полотні датчики і \\
утворюють контрольну ділянку, що дозволяє \\
визначити деякі параметри транспортного засобу, такі \\
як кількість і тип рухомих одиниць, іх осність та ін. \\
Знаходять застосування інноваційні системи \\
супутникової \\
\multicolumn{5}{c}{ навігації для слідкування за }
\end{tabular}

(С Л. А. Мурадян, В. Ю. Шапошник, 2017 переміщенням рухомого складу, який оснащений навігаційними датчиками. Однак практичне їх застосування наразі потребує значних фінансових витрат та має недостатню ефективність [2, 3].

\section{Формулювання мети}

Метою даної роботи $є$ вдосконалення методу автоматичної ідентифікації вагона та його окремих складових в рамках впровадження нових концепцій системи технічного обслуговування та ремонту.

\section{Основна частина дослідження}

Визначення експлуатаційної надійності вагона в реальних умовах, з врахуванням його пошкоджень в експлуатації та відновлення в ремонті, можливо при отриманні даних про експлуатацію вузлів і деталей вагона, які визначають його ресурс або міжремонтний період [4]. Підвищити точність та достовірність, зменшити помилки, зумовлені «людським фактором», при ручному отриманні інформації дозволяють САI. Аналіз впровадження CAI на залізничному транспорті виявив, що найбільш вдалими $\epsilon$ системи, які використовують телевізійно-цифрові комплекси та засоби радіочастотної ідентифікації на базі RFID технології.

Технологія і засоби оптичної ідентифікації вагонів застосовуються для розпізнавання та реєстрації ідентифікаційних номерів вантажних вагонів. Вони встановлюються на залізничних коліях підприємств та сортувальних станціях. Система забезпечує реєстрацію номерів рухомого складу, передачу результатів на рівень обробки і зберігання інформації, формує i вводить в персональний комп'ютер відеозображення 
зони контролю, виявляє та розпізнає ідентифікаційні оптичної схеми, погодних умов і часу доби в знаки і маркування, нанесені на об'єкт контролю, автоматичному режимі при швидкості руху об'єкта оповіщає оператора в разі невідповідності результатів, до160 км/год. У сумнівних ситуаціях остаточне записує інформацію та виводить її на друк. Програмне рішення приймає оператор на основі візуального забезпечення дозволяє розпізнавати дані з ймовірністю аналізу зображення, рис. 1 [5, 6].

$95 \%$ i вище, в широкому діапазоні параметрів

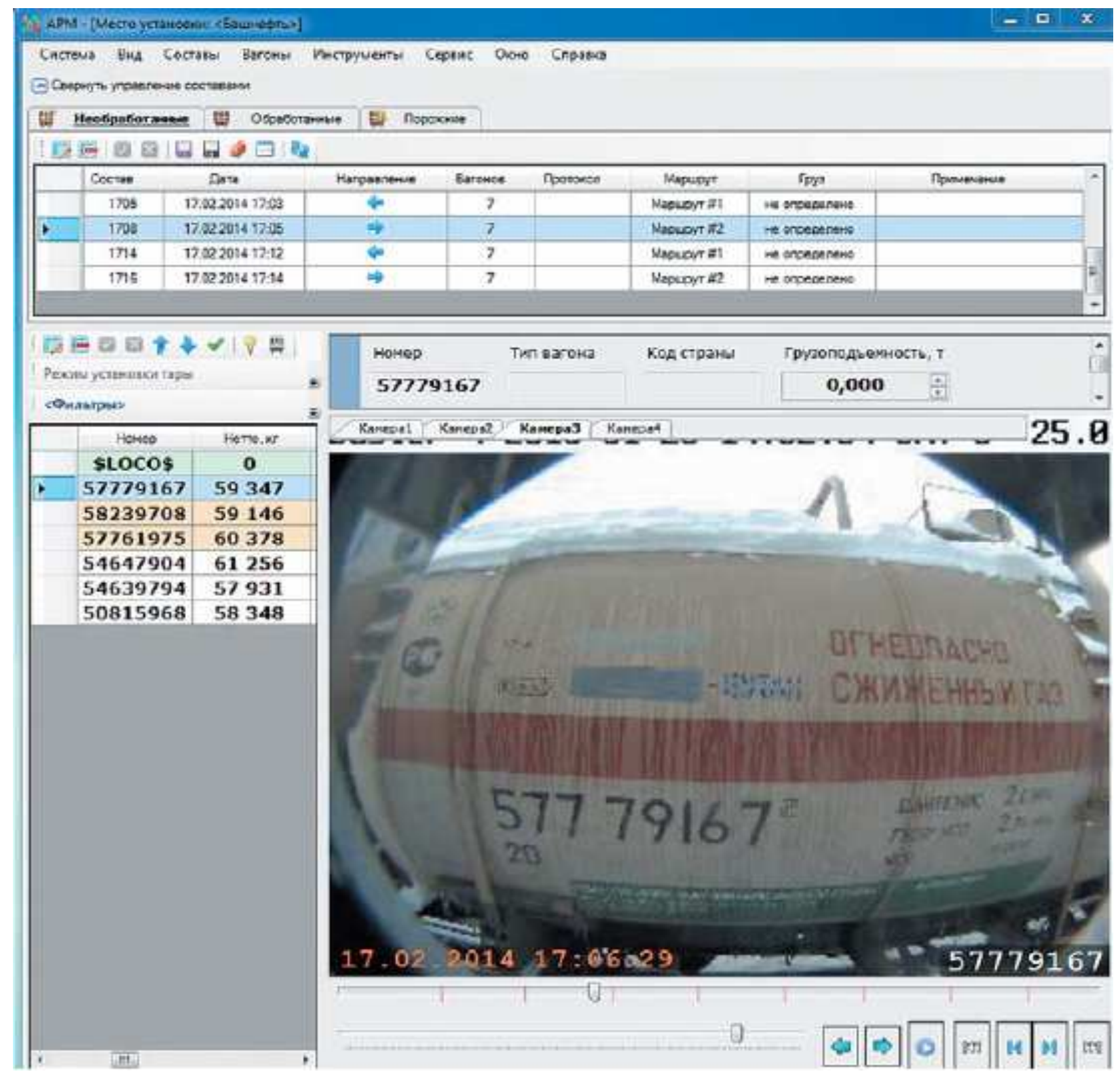

Рис. 1. Візуальне зображення об'єкта контролю та його ідентифікація (система ARSCIS розробки TOB «Малленом Системс»)

Більш інформаційно місткими та перспективними CAI, на наш погляд, $\epsilon$ засоби радіочастотної ідентифікації на базі RFID технології, якими оснащуються вагони, локомотиви, моторвагонний рухомий склад, контейнери. На рухомому складі встановлюються кодові бортові датчики (далі - КБД) що містять пасивну RFID мітку 3 занесеною в неї інформацією, а зчитувальні пристрої (рідери) розташовуються в контрольних точках вздовж колії (рис. 2, 3). 
a)
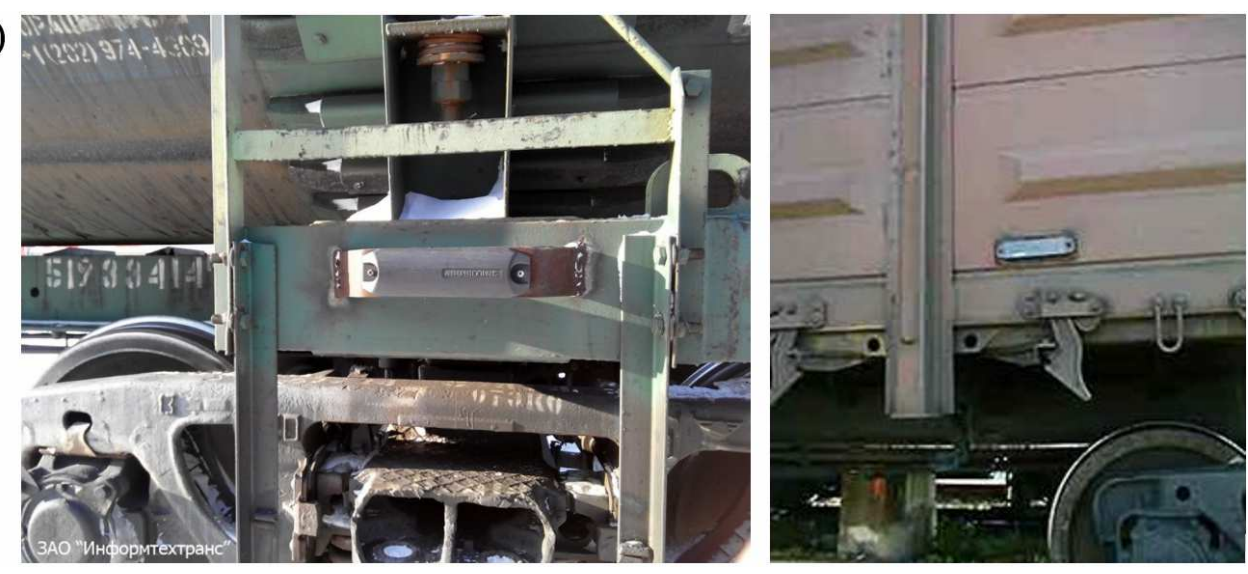

б)

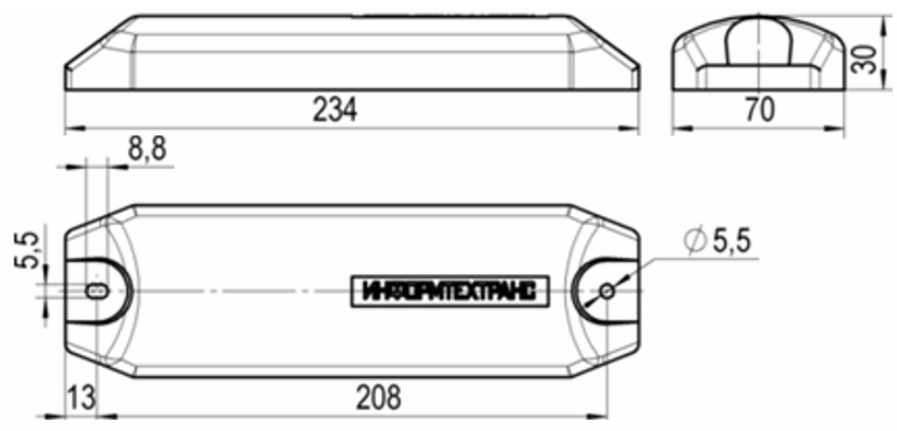

Рис. 2. Кодовий бортовий датчик:

a - розміщення КБД на вантажних вагонах;

б - габаритні розміри датчика КБД-2М, виконаного в пластиковому корпусі

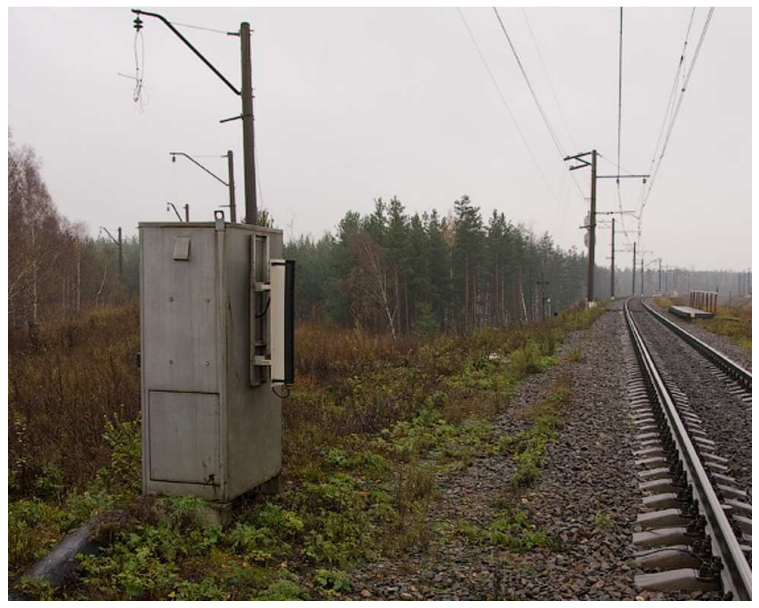

Рис. 3. Пункт зчитування інформації (рідер)

Відстеження переміщення залізничного транспорту за допомогою такої системи грунтується на визначенні проходження поїздом контрольних ділянок. КБД має унікальний код - радіочастотний відгук на опитувальний імпульс зчитувальних пристроїв, властивий тільки даній мітці. Інформаційна ємність КБД становить 128 біт, з них 31 біт використовуються для технологічних цілей (контроль помилок, захист від несанкціонованого дублювання датчиків та ін.), а 97 біт складають змістову область пам'яті загального призначення, в якій може зберігатися як постійна інформація про тип рухомого складу, код власника, номер одиниці рухомого складу, так i змінна інформація про код вантажу та станцію призначення. 
Пристрій для зчитування встановлюється поблизу від осі колії, при цьому дальність приймання і передачі при зчитуванні становить до 5 м. Варіанти закріплення міток на рухомому складі та розташування зчитувачів у контрольних пунктах показані на рис. 4 [7].

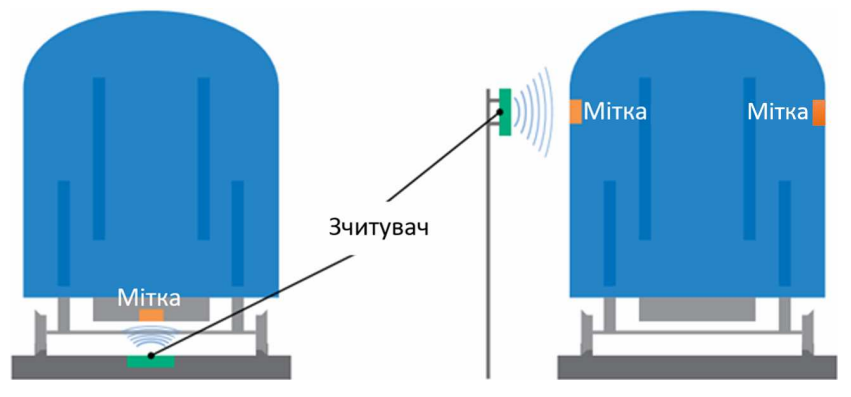

Рис. 4. Варіанти розміщення компонентів CAI на базі систем радіочастотної ідентифікації

Наразі як система радіочастотної ідентифікації, на базі технології RFID, на залізницях СНД застосовується СAI рухомого складу «Пальма», розрахована на роботу в діапазоні частот 880-900 МГц. Складові системи працюють при температурі навколишнього середовища від -50 до $+70{ }^{\circ} \mathrm{C}$ i відносній вологості навколишнього середовища до $100 \%$. КБД буде зчитуватися при покритті його шаром до 1 мм сажі, нафти, мазуту та зледенінні шаром до 3 мм. Система «Пальма» виконана відповідно до міжнародного стандарту ISO 10374 та сумісна 3 міжнародною системою Dynicom компаній Amtech i Alkatel [8]. Подальше впровадження таких систем на залізницях СНГ призупинено через недостатне фінансування [2].

Системи радіочастотної ідентифікації на базі технології RFID успішно застосовуються на залізницях різних країн. На залізницях Норвегії в 2013 році був запущений проект впровадження RFID-систем. Зчитувачі встановлювалися вздовж полотна та отримували інформацію з КБД на вагонах, визначаючи ï напрямок і швидкість за допомогою 3G/GPS. Також в систему надходила інформація від спеціальних детекторів контролю ходових частин. На французьких залізницях така система застосовується для контролю за експлуатацією локомотивів та швидкісних пасажирських потягів TGV. Канадська національна залізнична компанія у зв'язку із зростанням інтермодальних перевезень для збільшення пропускної спроможності терміналу замінила систему ручного обліку переміщень автоконтейнеровозів на автоматизовану систему на базі технології RFID, точність обліку при цьому різко підвищилася. У компанії з'явилася можливість точно визначити терміни оборотності транспорту, тобто час від моменту завантаження контейнера з залізничної платформи на контейнеровоз до моменту повернення порожнього контейнеровоза назад на термінал, який скоротився майже в два рази. Оператор гамбурзької приміської залізниці застосовує на своєму рухомому складі напівпасивні RFID-мітки, які розміщені в нижній частині кожного вагона, а зчитувачі встановлюються на шпалах у вузлових пунктах. Стандарт, прийнятий Асоціацією американських залізниць, передбачає оснащення залізничних вагонів маркерами CAI на основі технології RFID. Такими маркерами виробництва компанії Amtech в США обладнано вже майже $97 \%$ всіх залізничних транспортних засобів, при цьому їх впровадження окупилося вже в перший рік повномасштабного застосування [9].

Для автоматичної ідентифікації рухомого складу розроблений цілий ряд комплексів та систем, які мають свої недоліки та переваги. Одним 3 можливих шляхів їх подальшого розвитку повинна стати можливість автоматичної ідентифікації окремих вузлів, деталей та елементів вагона, з внесенням даних до електронної бази. Це дозволить створити повну інформаційну базу, яка буде містити відомості про стан вузлів і деталей протягом їх життєвого циклу та дозволить впровадити нові концепції CTOіР парку вантажних вагонів: за станом або 3 урахуванням пробігів у завантаженому та порожньому стані (за нормативами фактично виконаної роботи) $[10,11,12]$. Для створення такої системи потрібно визначити оптимальні CAI з точки зору надійності, точності, та тривалості життєвого циклу.

У різних галузях економіки набули поширення CAI на основі штрихкодів та QR-кодів. Такі засоби ідентифікації мають невеликі габарити, можуть бути швидко змінені за необхідності на нові, мають мінімальну вартість. Однак їх застосування на рухомому складі залізниць недоречно через те, що для їх зчитування вони повинні знаходитися в полі зору сканера та залишатися нерухомими. Вагомим недоліком штрихкодів та QR-кодів є підвищені вимоги до чистоти їхньої поверхні, яка для зчитування сканером повинна бути абсолютно чистою, що виконати в умовах експлуатації практично неможливо.

На думку авторів, найбільш повно вимогам достовірності функціонування в складних погодних умовах, опору впливам ударів і вібрації, простоти монтажу; забезпечення великого радіусу зчитування i ідентифікацій при швидкостях руху об'єкта до 160 км/год, а на швидкісних ділянках колії - 250 км/год і вище; непотребування технічного обслуговування; практично необмеженого терміну служби; непотребування джерела живлення для роботи мітки на вантажному рухомому складі; практично $100 \%$ достовірності ідентифікації; безпеки для людини та навколишнього середовища відповідають RFID системи для несамохідного рухомого складу та навігаційні датчики систем супутникової навігації для самохідного рухомого складу. 
Розглянемо детальніше конструкцію, виконання та принцип роботи RFID систем. RFID (Radio Frequency Identification) - це спосіб зберігання та передачі інформації з носія-мітки, за допомогою спеціальних зчитувальних пристроїв (рідерів). Система складається 3 трьох основних компонентів: зчитувача (рідера), мітки (транспондера) та комп'ютерної системи опрацювання даних.

Зчитувач має приймально-передавальний пристрій, який посилає сигнал до мітки та приймає відповідний сигнал від неї. Мітка, як правило, містить в собі антену, приймач, передавач, і пам'ять для зберігання даних, рис. 5. Енергію мітка отримує 3 радіосигналу антени зчитувача за рахунок індукційного струму 3 котушки або антени, в якій виробляється струм, коли мітка проходить через електромагнітне поле, або від власного джерела живлення. Після отримання зовнішнього сигналу мітка відповідає власним сигналом, в якому міститься запрограмована інформація.

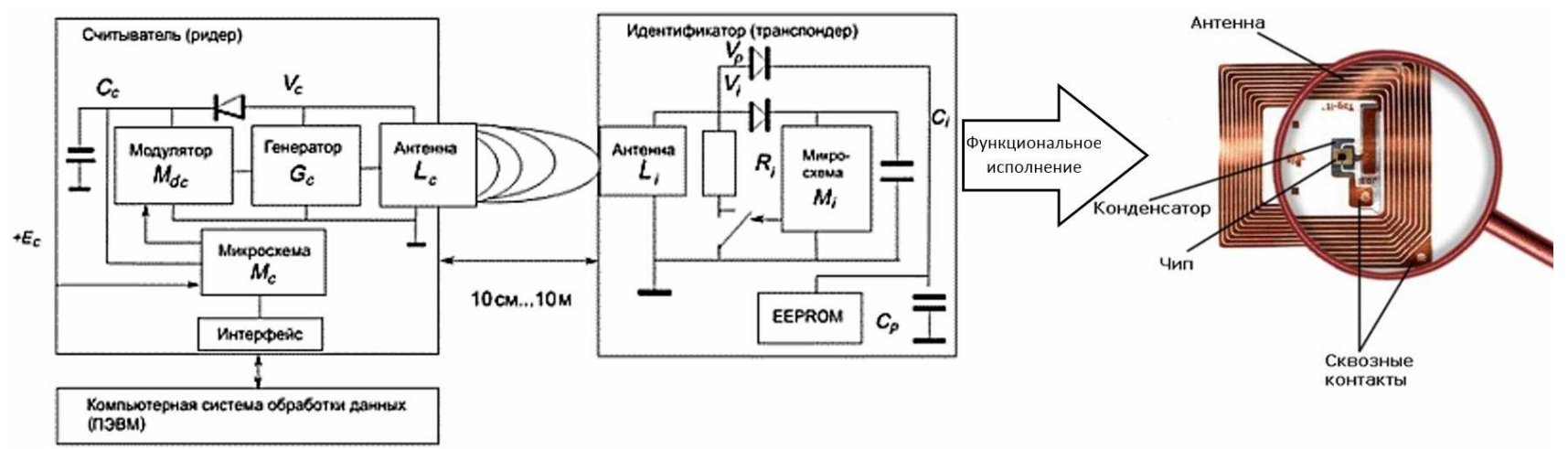

Рис. 5. Функціональна схема RFID системи

За типом використовуваної пам'яті RFID-мітки можуть бути таких типів:

- дані записуються тільки один раз, відразу при виготовленні (Read Only);

- мітки містять унікальний ідентифікатор та блок одноразово записуваної пам'яті, яку надалі можна багато разів читати (Write Once Read Many);

- мітки містять ідентифікатор і блок пам'яті для читання/запису інформації, дані в них можуть бути перезаписані багаторазово (Read and Write).

За типом джерела живлення RFID-мітки діляться так: пасивні, активні, напівпасивні. Пасивні RFIDмітки не мають вбудованого джерела енергії. Активні RFID-мітки мають власне джерело живлення i не залежать від енергії зчитувача, вони зчитуються на значній відстані, мають більший об'єм пам'яті, за необхідності можуть бути оснащені додатковою електронікою, але у порівнянні 3 пасивними вони дорожчі, мають більші розміри та обмежений час роботи. Напівпасивні RFID-мітки схожі на пасивні мітки, але оснащені батареєю, яка забезпечує чип енергоживленням, при цьому дальність дії цих міток залежить тільки від чутливості приймача зчитувача.

Пристрої для зчитування можуть бути стаціонарними або мобільними. Переносні мобільні зчитувачі можуть використовуватися як у вагонних депо, так і оглядачами вагонів в умовах експлуатації, вони мають внутрішню пам'ять, в яку записуються дані 3 прочитаних міток, рис. 6 [13].

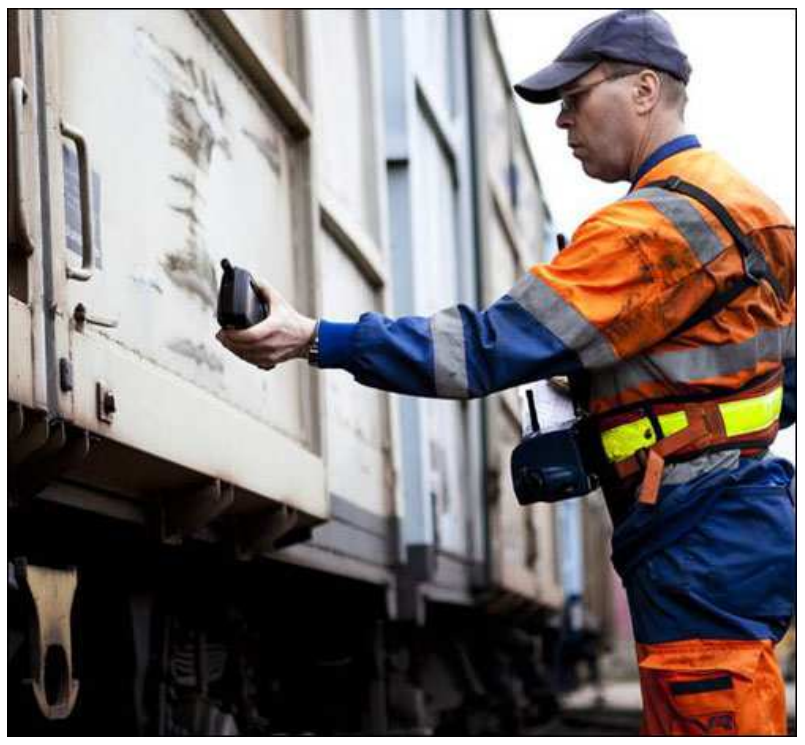

Рис. 6. Дистанційне зчитування даних з вагона

За дальністю зчитування RFID-системи можна поділити на такі системи:

- ближньої ідентифікації (зчитування проводиться на відстані до $20 \mathrm{~cm}$ );

- середньої ідентифікації (від 20 см до 5 м);

- дальньої ідентифікації (від 5 м до 300 м).

Дальність зчитування залежить від імпульсної потужності та швидкості проходження зчитувального пристрою (рис. 7) [14]. 


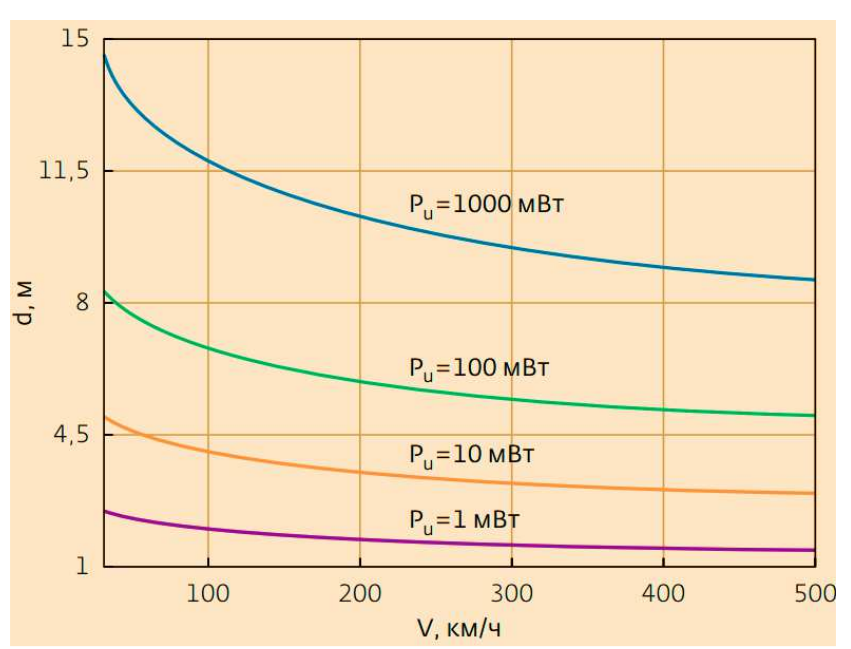

Рис. 7. Залежність дальності зчитування мітки при різній імпульсній потужності та швидкості руху рухомого складу

Розрахункова імовірність помилки RFID-технології становить не більше одного помилкового або невиявленого зчитування на 1 млн зчитувань.

Висновок 3 досліджень і перспективи подальшого розвитку у даному напрямку

Подальший розвиток САI вантажних вагонів повинен передбачати можливість автоматичної ідентифікації окремих вузлів та деталей вагонів. На думку авторів, найбільш повно вимогам, які ставляться до таких систем, відповідають засоби радіочастотної ідентифікації на базі технології RFID. Ідентифікація окремих деталей та вузлів, з занесенням та зберіганням даних в інформаційній базі, створить умови для переходу до нових систем технічного обслуговування та ремонту. Наступним кроком у вирішенні питання автоматичної ідентифікації окремих вузлів та деталей вагонів повинно стати встановлення їх переліку 3 точки зору їх впливу на надійність транспортної одиниці та безпеки руху. Важливим питанням, яке потребує вирішення у рамках цієї теми, є визначення мінімального об'єму необхідних інформаційних даних, який повинна містити мітка.

\section{Список використаних джерел}

1. Форд, Р. Идентификация и определение местоположения подвижного состава [Текст] / Р. Форд // Железные дороги мира. - 1999. - №8. C. 25-27.

2. Жуковицкий, И. В. Идентификация поездов в информационных системах железнодорожного транспорта [Текст] / И. В. Жуковицкий, О. И. Егоров // Системные технологии. - 2015. №5 (100). - C. 123-131.
3. Ромкин, М. В. Система автоматической идентификации типов подвижных единиц железнодорожного транспорта [Текст] / М. В. Ромкин, В. А. Засов // СамГУПС. - 2010. - С. 538-545.

4. Мямлін, С. В. Визначення параметрів експлуатаційної надійності вантажних вагонів у системі технічного обслуговування та ремонту [Текст] / С. В. Мямлін, Л. А. Мурадян, Д. М. Барановський // Залізничний транспорт України. - 2015. - № 4. - С. 12-17.

5. Современное вагоностроение [Текст]: монография; T. 2. Неразрушающий контроль и техническая диагностика. Подготовка поверхности и окраска вагонов / . Г. Цыган, А. Б. Цыган, С. Д. Мокроусов [и др.]. - Кременчуг: Кременчугская гор. типография, 2010. - 536 с.

6. Веснин, Е. Распознавание номеров вагонов: принципы решения и приложение в промышленности [Текст] / Е. Веснин, В. Царев, А. Михайлов // Control engineering Россия. - 2014. - №1 (49). - С. 60-66.

7. Система автоматической идентификации управления перемещением грузов на железнодорожном транспорте [Текст] / А. Багдасарян, С. Багдасарян, Г. Кащенко [и др.] // Электроника, наука, технология, бизнес. - 2013. №3 (00125). - С. 92-98.

8. «Пальма». Система автоматической идентификации транспортных средств [Текст] / В. В. Белов, В. А. Буянов, М. Д. Рабинович [и др.] // Железнодорожный транспорт. - 2002. - №8. C. 54-59.

9. Кейсы в сфере железнодорожных перевозок [Электронный peсурс]. - Режим доступа: http://gorfid.ru/cases/zh_d_perevozka/

10. Особливості технічного обслуговування та ремонту вантажних вагонів 3 підвищеними показниками надійності [Текст] / В. М. Бубнов, Л. А. Мурадян, М. Б. Манкевич [та ін.] // Зб. наук. праць Укр. держ. ун-ту залізнич. трансп. - Харків: УкрДУЗТ, 2016. - Вип. 160. - С. 11-17.

11. Мямлін, С. В. Определение стратегии технического обслуживания и ремонта вагонной техники [Текст] / С. В. Мямлін, Л. А. Мурадян, В. Ю. Шапошник // Транспортная инфраструктура Сибирского региона. Материалы VII-ой Междунар. науч.-техн. конф. - Иркутск: ИрГУПС, 2016. - C. 369-373

12. Esposito, V. Maintenance and repair of rolling stock [Text] / V. Esposito, S. Nocchia // Welding Institute. - 2008. - Vol.22. No.9. - P. 627-634.

13. RFID для железнодорожных вагонов [Электронный pecypc]. - Режим доступа: http://markerovka.ru/state/rfid_dlya_zheleznodorozhn ykh_vagonov.html. 
14. Николаева, С. О. Радиометка на поверхностных акустических волнах для систем радиочастотной идентификации [Текст]: дис... канд. техн. наук: 05.27.01 / С. О. Николаева [ФГБОУ ВО Воронежский государственный технический университет]. - Воронеж, 2016. - 200 с.

Мурадян Л.А., Шапошник В.Ю. Автоматическая идентификация отдельных частей транспортного средства при внедрении новых концепций системы технического обслуживания и ремонта. Целью работы является совершенствование метода автоматической идентификации вагона и его отдельных составляющих в рамках внедрения новых концепций системы технического обслуживания и ремонта.

Дальнейшее развитие систем автоматической идентификации грузовых вагонов должно предусматривать возможность автоматической идентификации отдельных узлов и деталей вагонов. По мнению авторов, наиболее полно требованиям, предъявляемым к таким системам, соответствуют RFID системы для несамоходного подвижного состава. Ключевые слова: подвижной состав, система автоматической идентификации, RFID системы, система технического обслуживания и ремонта.

Muradian L., Shaposhnyk V. Automatic identification of separate parts of vehicle with implementation of new concepts of maintenance and repair implementation. The objective of the research is to improve the method of automatic wagon identification and its parts as part of new concepts of maintenance and repair implementation. A changeover to new concepts of maintenance becomes possible thanks to improvement of automatic rolling stock identification. Taking into account service damages and their rebuilding service reliability rating in real conditions is possible thanks to wagon units and wagon parts data acquisition which estimates its resource and turnaround time.

Future development of automatic wagon identification should allow for separate units and wagon parts automatic identification. To authors view more complete demands are: under severe weather events functioning, strokes and vibration influence, ease of installation, big reading and identification radius providing, doesn't need maintenance, has perpetual lifetime, doesn't need the source of energy for sign work of freight rolling stock, has about $100 \%$ data reliability, safe for people and environment, it goes along with RFID systems for unpowered rolling stock.

Keywords: rolling stock, automatic wagon identification, RFID systems, maintenance and repair systems.

Надійила 30.08.2017p
Мурадян Леонтій Абрамович, канд. техн. наук, дочент кафедри «Вагони та вагонне господарство» Дніпропетровського національного університету залізничного транспорту імені академіка В. Лазаряна. E-mail: leontymuradian@gmail.com.ORCID:0000-0003$1781-4580$

Шапошник Владислав Юрійович, молодший науковий співробітник галузевої науково-дослідної лабораторії «Вагони», керівник з якості випробувальної лабораторіі вагонів Дніпропетровського національного університету залізничного транспорту імені академіка B. Лазаряна. E-mail: vladislav.sh91@gmail.com.ORCID 0000-0003-4701-6491

Muradian L., candidate of techn. sciences department «Car and Car Facilities» of Dnipropetrovsk National University of Railway Transport named after academician V. Lazaryan. E-mail: leontymuradian@gmail.com. ORCID: 0000-0003-1781-4580.

Shaposhnyk V. Junior research fellow, quality manager wagons Laboratory of Dnipropetrovsk National University of Railway Transport named after academician V. Lazaryan. E-mail: vladislav.sh91@gmail.com. ORCID 0000-0003-4701-6491. 